\title{
OBSERVATIONS ON FATIGUE CRACK GROWTH AND FATIGUE LIFE OF RIVETED LAP JOINTS
}

\begin{abstract}
SUMMARY
Effects of variables related to design and production of riveted lap joints representative of longitudinal sheet connections for a pressurized transport aircraft fuselage were experimentally investigated. The specimens from an aircraft $\mathrm{Al}$ alloy D16 Alclad sheets of three different thicknesses $(1.9,1.2$ and $0.8 \mathrm{~mm})$ were assembled under load control using round head rivets and rivets with the compensator from a P24 Al alloy. For the joints from $1.9 \mathrm{~mm}$ thick sheets fatigue tests indicated a dependency of the crack initiation site and crack path on the squeeze force level and on the rivet type. At the same time, increasing the squeeze force led to improved fatigue properties of the joints, specimens assembled using the rivets with the compensator showing fatigue lives consistently longer than joints with the round head rivets. All observed trends have been explained based on hole expansion and load transfer measurements. For thin sheets connected using the round head rivets, local deformations and indentations under the driven rivet head promoted crack initiation and failure in the adjacent sheet. Fatigue test results indicated that the detrimental effect of this type imperfections could outweigh the benefits associated with a decrease in secondary bending due to thinning the sheets. The rivets with the compensator were observed to cause significant local imperfections beneath the manufactured head, which adversely affected the joint fatigue performance.
\end{abstract}

Keywords: riveted joints, fatigue life, crack initiation, fatigue crack growth

\section{BADANIA ROZWOJU PĘKNIĘĆ I TRWAEOŚCI ZMĘCZENIOWEJ W ZAKŁADKOWYCH POŁACZENIACH NITOWYCH}

\begin{abstract}
Sposób zniszczenia $i$ wytrzymatość zmęczeniowa połaczeń zaktadkowych stosowanych $w$ lotnictwie zależy od wielu czynników technologicznych i konstrukcyjnych, a w szczególności od rodzaju nitu i sity jego zakuwania oraz grubości taczonych blach. W artykule omówiono te zagadnienia na przykładzie blach o różnych grubościach z lotniczego stopu aluminium D16, połaczonych zakładkowo za pomoca nitów z łbem kulistym ze stopu PA24. Próbki połaczeń poddawane były stałoamplitudowym obciążeniom zmęczeniowym przy różnych poziomach naprężeń nominalnych. Wykazano, że wraz ze wzrostem sity zakuwania nitów rośnie trwałość zmęczeniowa połaczenia, a tor pęknięcia oddala się od przekroju netto blachy. Zaobserwowano, że pęknięcia zmęczeniowe pojawiaja się w blasze, w której ekspansja otworów nitowych jest mniejsza, co z kolei zależy od rodzaju nitu. Trendy te wyjaśniono na podstawie wyników pomiarów ekspansji otworów nitowych wypetnionych nitami zakutymi przy użyciu różnych sit oraz z uwzględnieniem wyznaczonego eksperymentalnie względnego udziału poszczególnych rzędów nitów w transferze obciązenia. Stwierdzono, że nity z kompensatorem nie sq odpowiednie do taczenia cienkich blach; $w$ trakcie zakuwania powstaja znaczne deformacje złacza obnizajace jego własności zmęczeniowe.
\end{abstract}

Slowa kluczowe: połaczenia nitowe, trwatość zmęczeniowa, inicjacja pęknięć, rozwój pęknięć zmęczeniowych.

\section{INTRODUCTION}

Riveting remains a preferred method for connecting elements of an aircraft structure, though adhesive-bonded and riveted-bonded joints are also applied. A typical design solution for joining sheets of a pressurized transport aircraft fuselage in the longitudinal direction is a riveted lap joint, usually comprising three rivet rows, as shown in Figure 1. Due to eccentricities occurring in the overlap region for this type of a joint, the so-called secondary bending is induced under nominally axial loading on the sheets. The phenomenon of secondary bending can lead to considerably elevated stresses in the sheets and affects the mode of failure of the joint (Skorupa and Skorupa 2010).

The fatigue crack nucleation location, crack path geometry and fatigue properties of a riveted lap joint depend on the integrated effect of a number of factors related to joint design and production as well as loading conditions. This paper focuses on the influence of the squeeze force, sheet thickness and rivet type.

\section{SPECIMENS AND TESTING EQUIPMENT}

The configuration of three-row riveted lap joint specimens used in the fatigue tests is shown in Figure 2 and the specimens' dimensions are specified in Table 1 . The rivet row spacing $s=5 d$ ( $d$-rivet diameter) and the rivet pitch in row $p=5 d$ are typical for fuselage skin connections. The rivet holes were drilled according to the process specification of the Polish aircraft industry.

\footnotetext{
* AGH University of Science and Technology, Faculty of Mechanical Engineering and Robotics, Krakow, Poland; e-mail: askorupa@agh.edu.pl
} 


\section{Detail A}
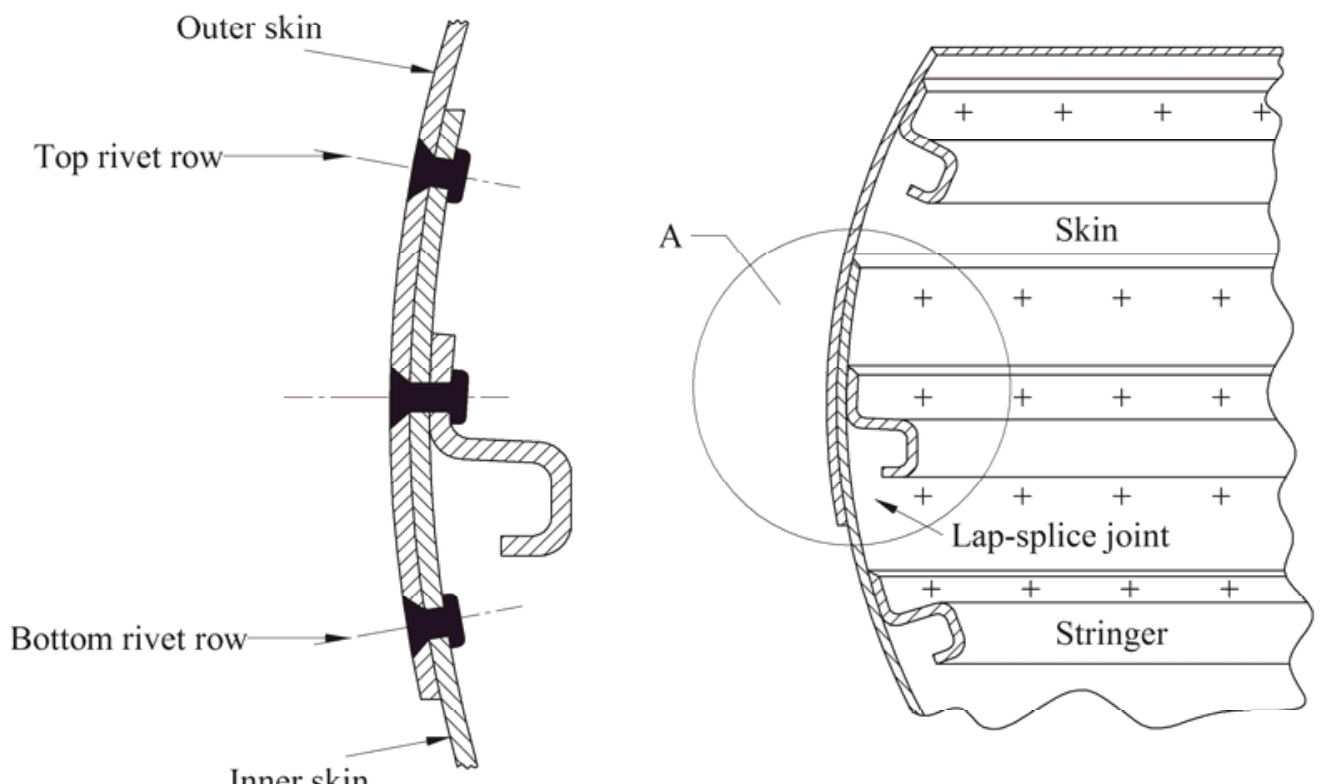

Circumferential

direction

Fig. 1. Typical fuselage longitudinal riveted lap splice joint

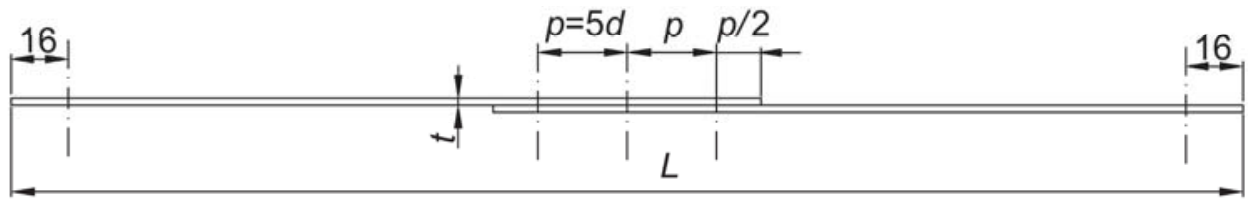

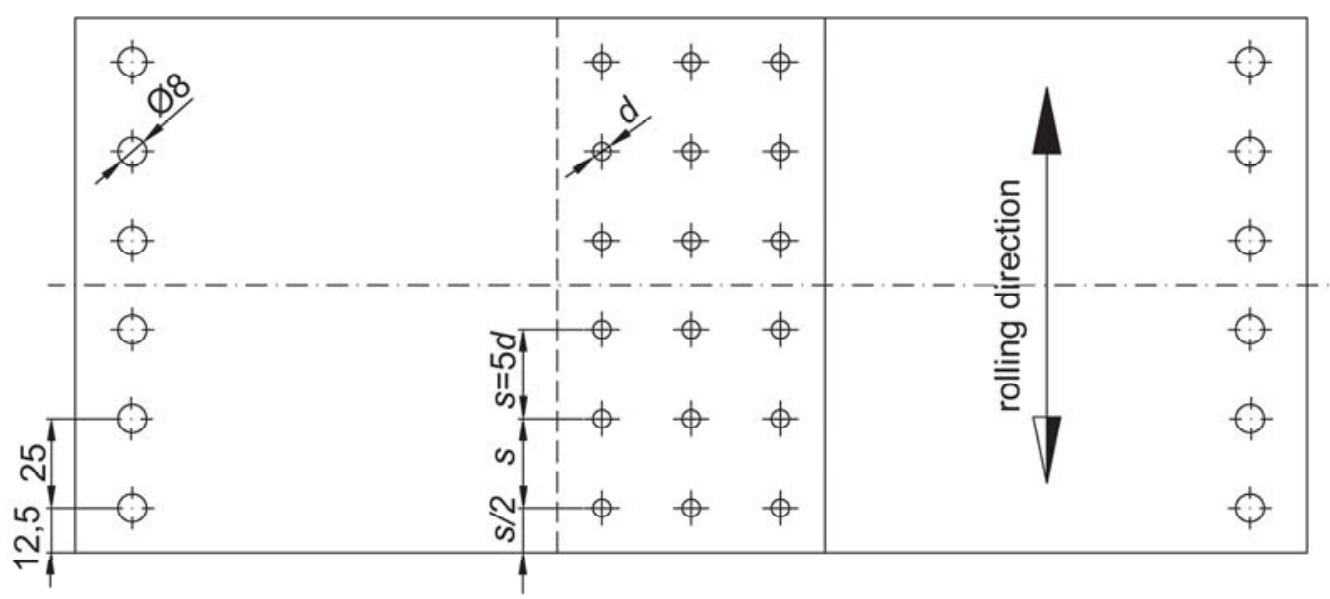

Fig. 2. Specimen for fatigue tests

Table 1

Characteristic dimensions of riveted specimens

\begin{tabular}{|c|c|c|c|}
\hline $\begin{array}{c}\text { Sheet thickness } \\
t, \mathrm{~mm}\end{array}$ & $\begin{array}{c}\text { Rivet diameter } \\
d, \mathrm{~mm}\end{array}$ & $\begin{array}{c}\text { Hole diameter } \\
d_{0}, \mathrm{~mm}\end{array}$ & $\begin{array}{c}\text { Specimen length } \\
L, \mathrm{~mm}\end{array}$ \\
\hline 0.8 & 3.5 & & 208 \\
\hline 1.2 & 4.0 & $(d+0.05)_{0}^{+0.12}$ & 260 \\
\hline 1.9 & 5.0 & & 345 \\
\cline { 2 - 3 } & & & \\
\hline
\end{tabular}


The total length $L$ of the specimens was chosen to eliminate the effect of specimen fixture in the fatigue machine on stress conditions in the overlap region (Müller 1995). The sheet material was a Russian Al alloy D16CzATWH in the Alclad condition. The mechanical properties $(0.2 \%$ yield stress $=291 \mathrm{MPa}$, ultimate strength $=433 \mathrm{MPa}$, elongation $=$ $13 \%$ ) and the fatigue crack growth behaviour of this material are similar to those of the western Al 2024-T3 alloy (Schijve et al. 2004). Two types of protruding head rivets differing in the manufactured head geometry, namely with a round head and with the so-called compensator were used to assemble the sheets, Figure 3. The compensator, which is a small pro- trusion on the mushroom rivet head, causes increased rivet hole expansion. The rivet material was the $\mathrm{P} 24 \mathrm{Al}$ alloy equivalent to the western 2117-T3 material used for the AD rivets. Force controlled riveting was applied using a squeezer mounted in the grips of a MTS 810 fatigue machine (Skorupa et al. 2010). The same machine was utilized in the fatigue tests carried out under constant amplitude loading at a stress ratio of 0.1 . This type of loading simulates variations of the hoop stress in the fuselage skin generated due to the cabin pressurization. Crack growth on the sheet surface was monitored using a travelling microscope. The testing equipment is shown in Figure 4. a)

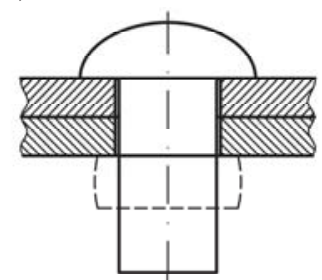

b)

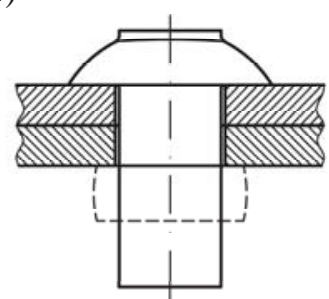

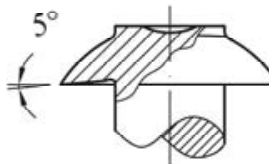

Fig. 3. Rivet types used in experiments: a) round head rivet; b) rivet with compensator

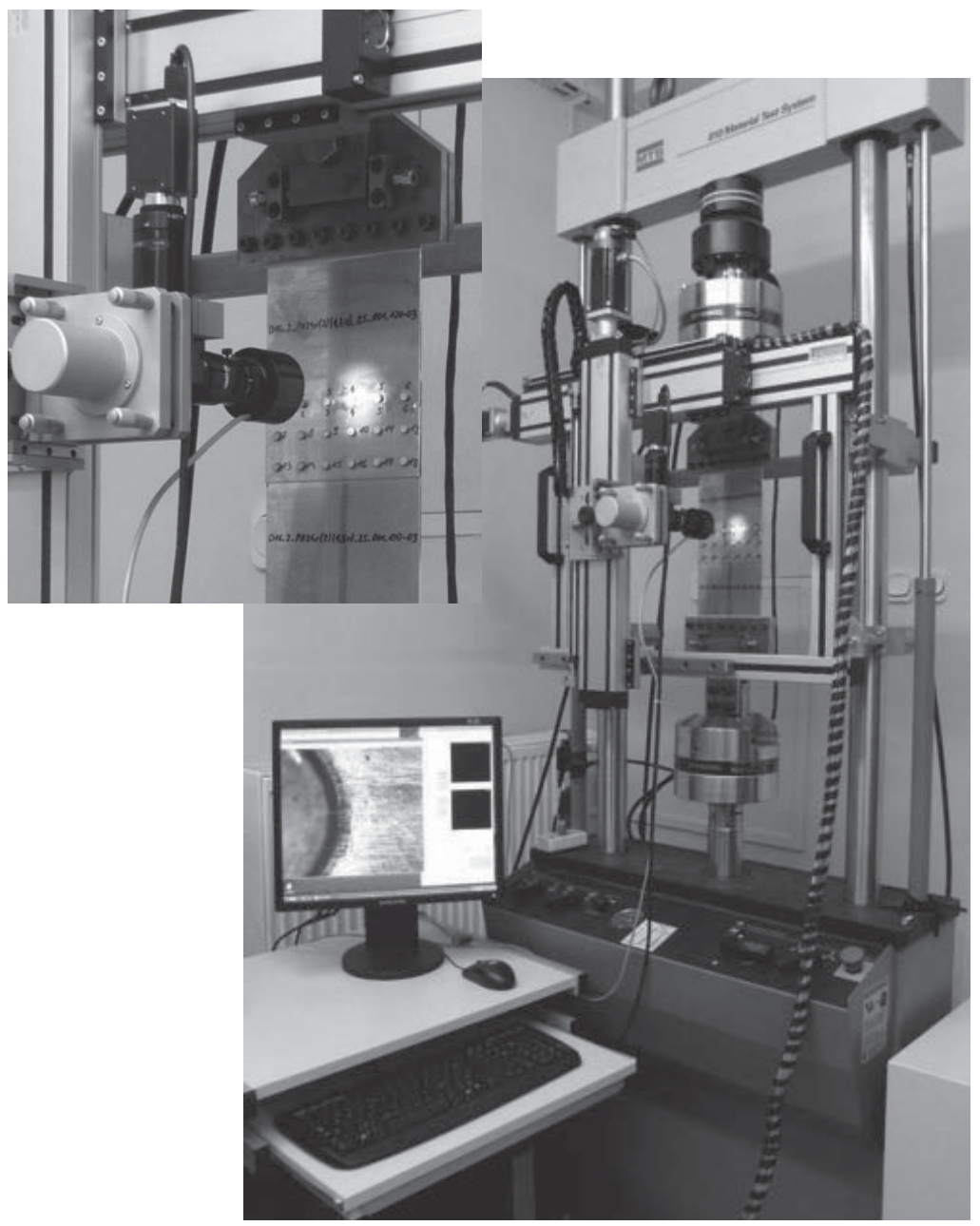

Fig. 4. Fatigue testing equipment 


\section{EFFECT OF THE SQUEEZE FORCE}

In production practice, the squeeze force is represented by a ratio of the rivet driven head diameter $(D)$ to the rivet shank diameter $(d)$ which increases with the squeeze force level. The $D / d$-value is, therefore, a first indicator of the riveting process quality. Typical $D / d$ ratios range from 1.3 to 1.5 , the latter value being considered as optimal (Müller 1995). The rivet installation causes rivet hole expansion, which generates compressive residual tangential stresses in the hole vicinity. The higher the squeeze force level, the larger the compressive tangential stress area, which affects the initiation location and path of fatigue cracks at rivet holes and the joint fatigue life. The increasing squeeze force yields also a higher residual clamping between the sheets beneath the rivet heads. This leads to transmitting a portion of the applied load by friction, which again can influence a mode of joint failure. As an example, Table 2 gives fatigue test results observed under an applied maximum cyclic stress $S_{\max }=120$ MPa for specimens from $1.9 \mathrm{~mm}$ thick sheets with round head rivets installed using four different squeeze force levels resulting in four different $D / d$-values.

A trend of increasing the fatigue life with the squeeze force, demonstrated in Table 2, was also exhibited at $S_{\max }$ of 100 and $80 \mathrm{MPa}$, but no impact of the stress level on the location of crack nuclei and crack path was found.

An illustration of the results from Table 2 are fractographic observation results shown in Figure 5. It is seen that fatigue cracks always initiate on the faying surface in one of end rivet rows, which results from the influence of secondary bending (Skorupa and Skorupa 2010). For a limited squeeze force, the cracks initiate at the edge of the rivet hole and propagate in the net cross section (Fig. 5a). A more intense squeezing of the rivet leads to crack initiation outside the hole, but propagation through the hole, usually shifted above the net cross section, (Fig. 5b). At a relatively high squeeze force fatigue cracks nucleation occurs above the hole near the edge of the clamping area beneath the rivet head, and the crack propagates outside the hole (Fig. 5c). The latter behaviour is partly contributed by fretting (Skorupa and Skorupa 2012).

Table 2

Fatigue lives and crack behaviour for specimens riveted with different squeeze forces

\begin{tabular}{|c|c|c|c|}
\hline$D / d$ & $\begin{array}{c}\text { Fatigue } \\
\text { life* } \\
\text { kcycles }\end{array}$ & $\begin{array}{c}\text { Crack initiation site, } \\
\text { Crack shape }\end{array}$ & Crack path \\
\hline 1.3 & 81.6 & $\begin{array}{c}\text { Under driven head, } \\
\text { Quarter elliptical }\end{array}$ & $\begin{array}{c}\text { Net cross } \\
\text { section }\end{array}$ \\
\hline 1.4 & 160.0 & $\begin{array}{c}\text { Under driven head, } \\
\text { Quarter elliptical }\end{array}$ & $\begin{array}{c}\text { Above net } \\
\text { section, } \\
\text { through rivet } \\
\text { hole }\end{array}$ \\
\hline 1.5 & 235.5 & $\begin{array}{c}\text { Under manufactured head, } \\
\text { Quarter/semi-elliptical }\end{array}$ & $\begin{array}{c}\text { Under manufactured head, } \\
\text { Semi-elliptical }\end{array}$ \\
\hline 1.6 & 298.2 & $\begin{array}{c}\text { Outside rivet } \\
\text { hole }\end{array}$ \\
\hline
\end{tabular}

* Average from three tests

It is seen in Table 2 that the specimens with $D / d$ of 1.5 and 1.6 always failed in the sheet adjacent to the rivet manufactured head, while in the case of $D / d \leq 1.4$ the crack nucleation and failure occurred in the sheet under the driven head. The above behaviour can be explained based on rivet hole expansion measurements shown in Figure 6 and load transfer measurements shown in Figure 7. In Figure 6, hole expansion is defined as $h e=\left(d_{e}-d_{o}\right) / d_{o}$, where $d_{e}$ is the expanded hole diameter. As shown in Figure 6 , for $D / d$ of 1.5 and 1.6 , he in the sheet next to the rivet driven head considerably exceeds that in the sheet next to the manufactured head. a)
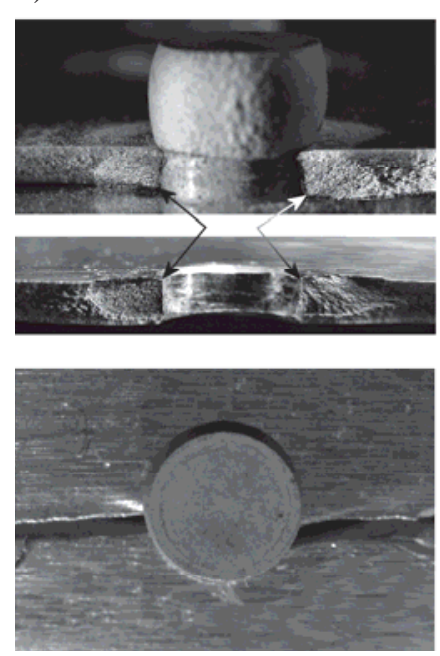

b)
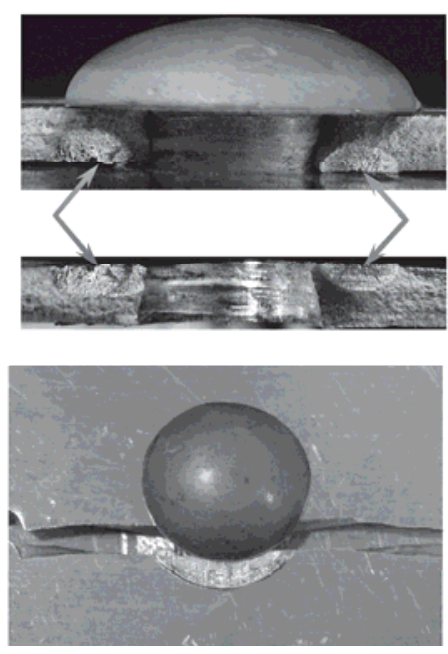

c)
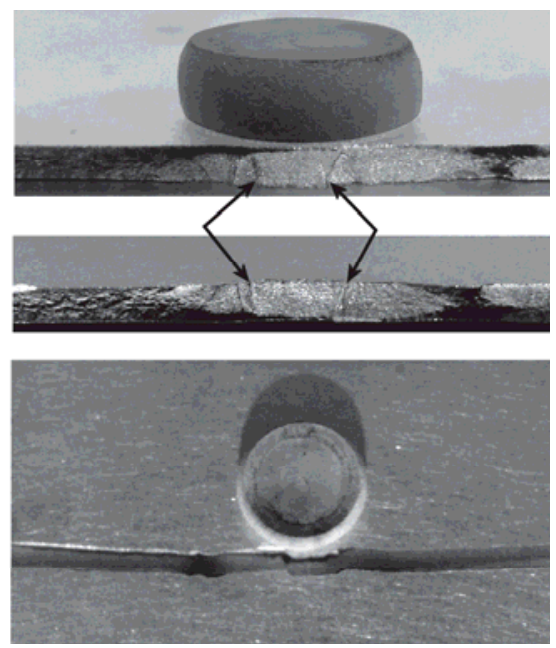

Fig. 5. Effect of squeeze force on fatigue crack initiation and path. Explanation in text 
At the same time, Figure 7 demonstrates that loads transferred by the end rivet rows are almost equal. Consequently failure occurs in the sheet with smaller hole expansion, i.e. under the manufactured head. For $D / d \leq 1.4$ he in both sheets is relatively small and only slightly larger under the driven head (Fig. 6). In that case, the negative influence of a much higher transfer load in the sheet adjacent to the driven head (Fig. 7) dominates and determines the failure location. A more uniform load transmission distribution for $D / d$ of 1.5 compared to $D / d$ of 1.3 shown in Figure 7 stems from lower flexibility of rivets installed with a higher squeeze force (Skorupa and Skorupa 2010).

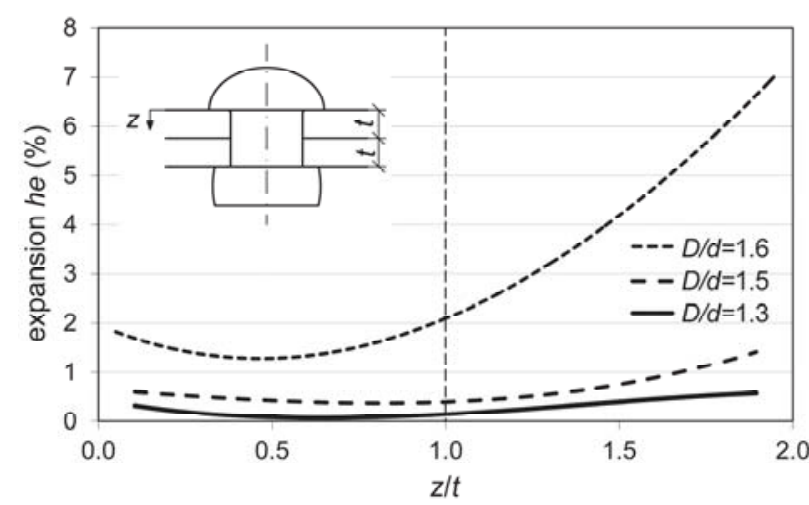

Fig. 6. Hole expansion measurement results. Round head rivet, sheet thickness $t=1.9 \mathrm{~mm}$

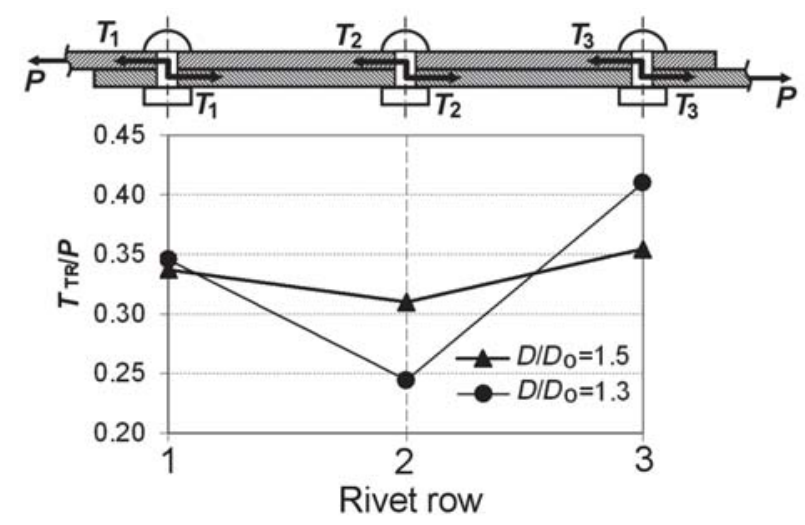

Fig. 7. Load transfer distribution in riveted joint for two squeeze force values. Round head rivet, sheet thickness $t=1.9 \mathrm{~mm}$

Figure 8 shows measurement results on he for the rivet with the compensator for two $D / d$-values. From a comparisons with Figure 6 is seen that due to the compensator he in the sheet next to the manufactured head becomes considerably larger than for the standard, round head geometry. Figure 8 indicates that he below the manufactured head of the rivet with the compensator is larger than below its driven head, which explains why in all fatigue tests on specimens assembled using this type of rivet fatigue failure occurred in the sheet adjacent to the rivet driven head. Similarly, as in the case of specimens with the round head rivets, a high- er squeeze force yielded an increase in the fatigue life. For a given $D / d$ ratio, fatigue lives of specimens assembled using the rivets with the compensator observed at $S_{\max }=120$ and $100 \mathrm{MPa}$ were by 40 to $90 \%$ higher than for specimens with the round head rivets.

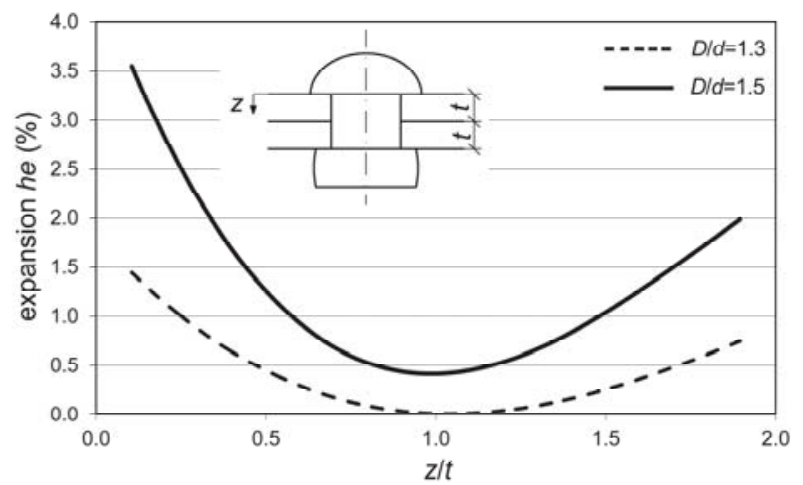

Fig. 8. Hole expansion measurement results. Rivet with compensator, sheet thickness $t=1.9 \mathrm{~mm}$

\section{EFFECT OF SHEET THICKNESS}

In order to assess the effect of sheet thickness on the mode of failure and fatigue properties of the joint, specimens from $0.8 \mathrm{~mm}$ and $1.2 \mathrm{~mm}$ thick sheets were fatigue tested in addition to the specimens from the 1.9 thick sheet considered in the previous section. The sheets were connected using round head rivets applying two different squeeze force values leading to $D / d$ of 1.3 and 1.5 for either specimen series. The fatigue tests were carried out at three $S_{\max }$ stress values, namely 120,100 and 90 or $80 \mathrm{MPa}$. In the case of the $D / d=1.3$ specimens, the crack path for both sheet thicknesses and at all load levels was through the rivet holes, slightly above the net section (Fig. 9). With the $D / d=1.5$ specimens, the cracks initiated and propagated above the rivet holes (Fig. 10). In all cases failure took place in the sheet adjacent to the rivet driven head. It can be concluded from confronting the above observations with information in Table 2 that the mode of failure for joints from the thin sheets $(0.8$ and $1.2 \mathrm{~mm})$ is different than in the case of joints from the thicker sheets $(1.9 \mathrm{~mm})$. The reason behind the above differences can be local deformations and indentations under the rivet driven head that occur during the rivet installation in thin sheets due to their low stiffness. Note that the driven head diameter is smaller than the manufactured head diameter (about $2 d$ ).

Results presented in Table 3 indicate that sheet thickness has an impact on the joint fatigue life. Increasing sheet thickness should yield a lower fatigue life due to the effect of secondary bending. For example, at $S_{\max }$ of $120 \mathrm{MPa}$ the bending factor $k_{b}=S_{b} / S_{\max }$, where $S_{\mathrm{b}}$ is the nominal bending stress computed according to Schijve's model (Schijve 1972), equals 1.1 and 0.85 for $t=1.9$ and $0.8 \mathrm{~mm}$ respectively. For $S_{\max }=80 \mathrm{MPa}$, still higher $k_{b}$ factors of 1.25 and 0.9 are obtained for the above $t$-values (Skorupa and Skorupa 2010). 


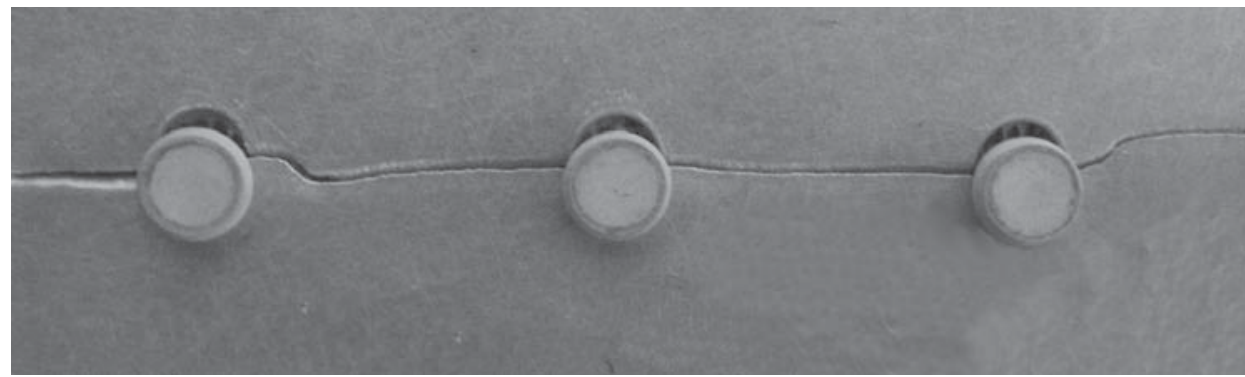

Fig. 9. Failure mode for specimen from 1.2 thick sheets and round head rivets. $D / d=1.3, S_{\max }=90 \mathrm{MPa}$

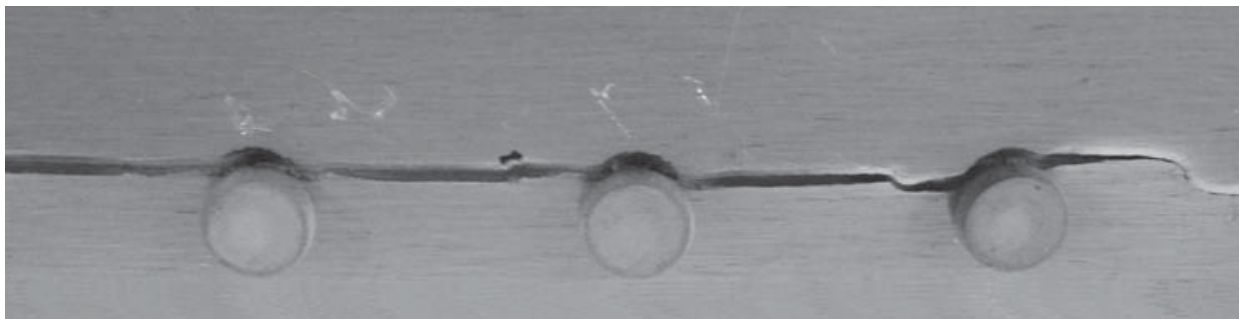

Fig. 10. Failure mode for specimen from 0.8 thick sheets and round head rivets. $D / d=1.5, S_{\max }=120 \mathrm{MPa}$

However, as seen in Table 3, the observed effect of thickness on the fatigue life is not systematic, due to the addressed above imperfections inherent in the joints.

Applying the rivets with the compensator to connect thin sheets brings no benefits compared to the round head rivets because, due to a specific shape of the manufactured head bottom surface (cf. Fig. 3a), significant local imperfections of the sheet beneath that head precipitate failure. For the above reason, fatigue cracks develop in the sheet under the manufactured head and can grow outside the rivet hole (Fig. 11).

\section{Table 3}

Fatigue lives (kcycles) for specimens of different thicknesses

\begin{tabular}{|c|c|c|c|c|c|c|}
\hline$S_{\max }, \mathrm{MPa}$ & \multicolumn{2}{|c|}{120} & \multicolumn{2}{c|}{100} & \multicolumn{2}{c|}{90} \\
\hline$D / d$ & 1.3 & 1.5 & 1.3 & 1.5 & 1.3 & 1.5 \\
\hline$t=0.8 \mathrm{~mm}$ & 288.5 & 322.2 & 483.0 & 1666.1 & 743.6 & 1665.0 \\
\hline$t=1.2 \mathrm{~mm}$ & 177.0 & 396.4 & 347.7 & 768.5 & 586.8 & 1135.4 \\
\hline$t=1.9 \mathrm{~mm}$ & 81.6 & 235.5 & 257.2 & 355.0 & $507.3^{*}$ & $1174.5^{*}$ \\
\hline
\end{tabular}

* Results for $S_{\max }=80 \mathrm{MPa}$
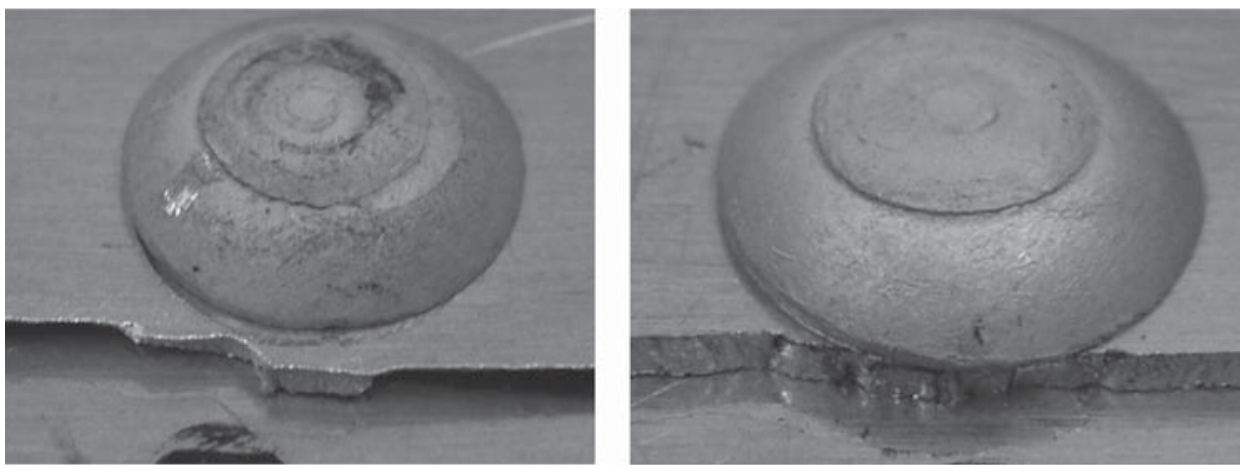

Fig. 11. Typical failure mode for specimen from thin sheets and rivets with compensator. $t=0.8 \mathrm{~mm}, D / d=1.4, S_{\max }=120 \mathrm{MPa}$ 


\section{CONCLUSIONS}

Experimental observations presented in the paper lead to the following conclusions:

1. The initiation and growth of fatigue cracks in riveted lap joints and the joint fatigue performance depend on rivet hole expansion, and hence on the rivet type and rivet squeeze force, as well as on the sheet thickness.

2. Fatigue cracks initiate always at the faying surface of the sheets in one of the outer rivet rows. Essentially, failure occurs in a sheet with smaller hole expansion, but the distribution of load transfer through the joint can also play a role. For the round head rivet, smaller hole expansion occurs in the sheet below the manufactured head, while for the rivet with the compensator smaller expansion is observed in the sheet adjacent to the driven head. For relatively low rivet squeeze forces the crack path is close to the net cross section along one of the outer rivet rows. At high squeeze forces the crack can start and grow outside the rivet hole. Fatigue life increases with the squeeze force value.

3. The above observations are not valid for joints from thin sheets. For round head rivets, the riveting process can locally introduce imperfections in the sheet adjacent to the rivet driven head, which promotes crack nucleation at this location. In this case, no systematic dependency of the joint fatigue life on the sheet thickness is exhibited.
Rivets with the compensator are not suitable for connecting thin sheets because significant local imperfections beneath the manufactured head cause a premature failure at that location.

\section{Acknowledgements}

Financial support from the National Science Centre within the projects Nos. N N502 338936 and DEC-2011/03/B/ ST8/05473 is acknowledged.

\section{References}

Müller R.P.G. 1995, An experimental and analytical investigation on the fatigue behaviour of fuselage riveted lap joints. The significance of the rivet squeeze force, and a comparison of 2024-T3 and Glare 3, $\mathrm{PhD}$ thesis, Delft University of Technology, Delft.

Schijve J. 1972, Some elementary calculations on secondary bending in simple lap joints, Report NLR TR 72036, National Aerospace Laboratory, Amsterdam.

Schijve J., Skorupa M., Skorupa A., Machniewicz T., Gruszczyński P. 2004, Fatigue crack growth in the aluminium alloy D16 under constant and variable amplitude loading, Int. J. Fatigue, vol. 26, pp. 1-15.

Skorupa A., Skorupa M. 2012, Riveted lap joints in aircraft fuselage. Design, Analysis and properties, Solid Mechanics and Its Applications Bookseries, Springer.

Skorupa M., Skorupa A. 2010, Load transmission and secondary bending in lap joints of aircraft fuselage, Fatigue of Aircraft Structures Monographic Series, A. Niepokólczycki (Ed.), Institute of Aviation Scientific Publications, Warsaw.

Skorupa M., Skorupa A., Machniewicz T., Korbel A. 2010, Effect of production variables on the fatigue behaviour of riveted lap joints, Int. J. Fatigue, vol. 32, pp. 996-1003. 